\title{
A demographic perspective on the spatial behaviour of hikers in mountain areas: the example of Berchtesgaden National Park
}

\author{
Johannes Schamel \\ Keywords: demographic change, spatial behaviour, GPS tracking, outdoor recreation, Berchtesgaden NP
}

\section{Abstract}

In Germany, as in many Western societies, demographic change will lead to a higher number of senior visitors to natural recreational areas and national parks. Given the high physiological requirements of many outdoor recreation activities, especially in mountain areas, it seems likely that demographic change will affect the spatial behaviour of national park visitors, which may pose a challenge to the management of these areas. With the help of GPS tracking and a standardized questionnaire $(n=481)$, this study empirically investigates the spatial behaviour of demographic age brackets in Berchtesgaden National Park (NP) and the potential effects of demographic change on the use of the area. Cluster analysis revealed four activity types in the study area. More than half of the groups with visitors aged 60 and older belong to the activity type of Walker.
Profile

Protected area

Berchtesgaden NP

Mountain range

Alps

Country

\section{Germany}

\section{Introduction}

In Germany and other European countries, demographic change already affects different aspects of society. The Federal Statistical Office forecasts that Germany's population will age rapidly in the next years and the share of people aged $60+$ will rise from $27.4 \%$ in 2014 to $36.7 \%$ in 2040 (Destatis 2015).

Managers of protected areas, especially in mountain areas, have to rethink all aspects of visitor management, including educational programmes, activities offered and lastly their infrastructure to meet the needs of future seniors (Eagles 2007). Therefore it is crucial to understand the connection between age and the spatial and temporal behaviour of visitors, as an effective visitor management should be based on sound distribution data (Hallo et al. 2012; Job 1991).

The spatial behaviour of outdoor recreationists like hikers is influenced by many factors. According to Beeco and Hallo (2014) these can be grouped into the following categories: visitor personal characteristics, user group type, knowledge of destination, resources and constraints and the infrastructure of the area. Various studies confirmed the relevance of these factors, for example, the influence of visitor personal characteristics like motivation and skill (Beeco \& Hallo 2014; McFarlane et al. 1998; Farias Torbidoni et al. 2005; Meijles et al. 2014; Wolf \& Wohlfart 2014), the role of previous knowledge (Beeco et al. 2012; McFarlane et al. 1998) or the influence of the infrastructure (Taczanowska 2009; van Marwijk 2009). Arrowsmith et al. (2005) found that senior visitors stay shorter and cover less distance - a pattern that was also followed by groups with small children (Meijles et al. 2014). In contrast, Beeco and Hallo (2014) did not find any correlation between age and trip length. However, all studies were conducted in flat areas and results are not transferable to mountain areas. Rupf $(2015,170)$ and Trachsel and Backhaus (2011) found that older visitors prefer shorter and less demanding trips when hiking in the Alps, but results were drawn from data on stated preferences, not actual spatial behaviour.

When uncovering differences in spatial behaviour between age brackets, one has to keep in mind that age has not an influence per se, but it can serve as a proxy variable on all age-related impacts, like increasing health restrictions that shape the spatial behaviour of the visitors (Breuer et al. 2010).

In the context of demographic change, several studies forecast future behaviour of age brackets based on a cross-sectional study (Bowker et al. 2006). This approach has weaknesses, as age, cohort and period effects occur simultaneously in cross-sectional studies (Pennington-Gray et al. 2002). Nevertheless, in the absence of appropriate longitudinal data, forecasting future behaviour based on a cross-sectional study can serve as the second best alternative if theoretical reasoning is possible why a dominant age, period or cohort effect can be assumed (Bowker et al. 2012).

Therefore several research questions emerged for the study area Berchtesgaden NP: How can visitors pursuing activities on foot be segmented according to their spatial behaviour? Are there turning points in the life cycle, where spatial behaviour changes? How might frequentation of trails be affected by demographic change?

\section{Methods and data}

\section{Study area}

Berchtesgaden NP is the only Alpine NP in Germany and covers an area of $208 \mathrm{~km}^{2}$. The elevation ranges from Lake Königssee (603 m) to Mount Watzmann $(2713 \mathrm{~m})$ and hiking infrastructure consists of 
Table 1 - Visitor characteristics by age group. " refers to group; ${ }^{b}$ refers to group leader / respondent; ' rated on a scale 1 (best) to 5 (worst), refers to maximum in group; ${ }^{d}$ refers to youngest group member if it is younger than 15, otherwise oldest group member; ${ }^{*} p<0.05 .{ }^{* *} p<0.01 .{ }^{* * *} p<0.001 ;{ }^{\circ}$ Chi-square test; ${ }^{f}$ ANOVA; ${ }^{g}$ Kruskal-Wallis-test

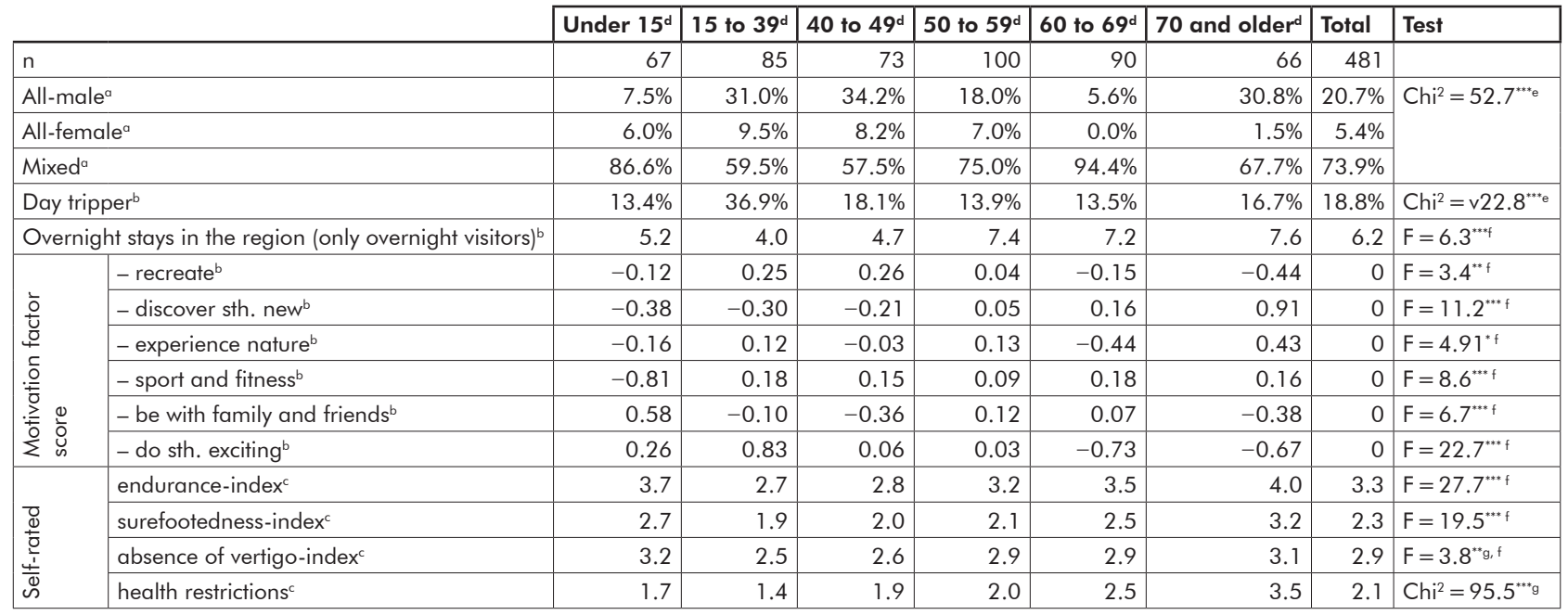

more than $250 \mathrm{~km}$ of marked hiking trails, alpine huts, as well as three means of transportation (see Figure 3) (Vogel 2011).

1.58 million visitors were counted in the area in 2014, which means a strong rise in visitor numbers since 2002 (Metzler et al. 2016). Concentrations of visitors occur around Lake Königssee as well as at Mount Jenner and almost $95 \%$ of the visitors discover the NP on foot.

Multiple reasons were decisive for selecting this study area. It provides a broad range of acitvities on foot at different skill levels. As a NP it is likely to see only very limited or no changes in the hiking infrastructure, which is useful for simulating scenarios. Lastly, the area is in a dead end situation with only a limited number of access points.

\section{Data collection}

Several types of information are needed to answer the research questions. Manual counts, including randomly sampled short interviews $\left(n_{1}=9460\right)$ covering duration of stay and age were conducted on 20 days throughout the year at seven main access points. Based on these counts, we calculated the total number of visitor days per age bracket, interview location and season following the methodology of Job et al. (2005) and Job \& Metzler (2005).

Visitor characteristics were recorded in personal on-site interviews on ten days in the same year. Respondents had to be at the beginning of their trips to participate in the study and convenience sampling was applied with a response rate of $37.2 \%$. Main reasons for refusal to participate were lack of time or inconvenience, and a minority of participants also mentioned discomfort with carrying a GPS logger. A consumer-grade GPS logger (TranSystem i-blue 747Pro) was handed out to the respondents to record spatial behaviour and logged the position every two seconds. Visitor characteristics were obtained with a standardized questionnaire and matched to spatial behaviour with a common key variable. If groups were encountered, the interview was conducted with the person who was mainly responsible for the planning of the trip. In total, 676 GPS trajectories with corresponding questionnaires were collected. After deducting tranjectories with loss of GPS signal, logging of other activities like backcountry skiing, or cases of returned questionnaires of poor quality, the sample size was reduced to $\mathrm{n}_{2}=481(71.1 \%)$.

Trail network and points of interest

A geo-database with additional information about the trail network was constructed in ArcGIS 10.2.2. Slope of the trails was calculated based on a $10 \mathrm{~m}$ Digital Elevation Model of the area. Trail difficulty was rated by two local experts in one of four categories: barrier-free trails (scale 1), trails with an even surface without danger of falls (scale 2), trails with rough surface without danger of falls (scale 3), trails with danger of falls (scale 4). Land use along trails was classified in five distinct categories: forest, grassland, rock, lakeside paths and infrastructure. Trails were classified as lakeside paths if they were within $50 \mathrm{~m}$ of bigger water bodies. Frequentation of trails was calculated by weighting the trajectories by the number of visitors at the starting point. Viewshed tool from ArcGIS was used to determine the visible area every $100 \mathrm{~m}$.

Points of interest, food outlets, as well as mountain peaks and stops for the bus, recreational shipping and the cable car were added to the geo-database.

\section{Post-processing of GPS data}

After importing to ArcGIS and projecting from WGS84 to Gauß-Krüger, GPS data were post-processed following the steps proposed by Kerr et al. (2011): data filtering and smoothing, detection of 


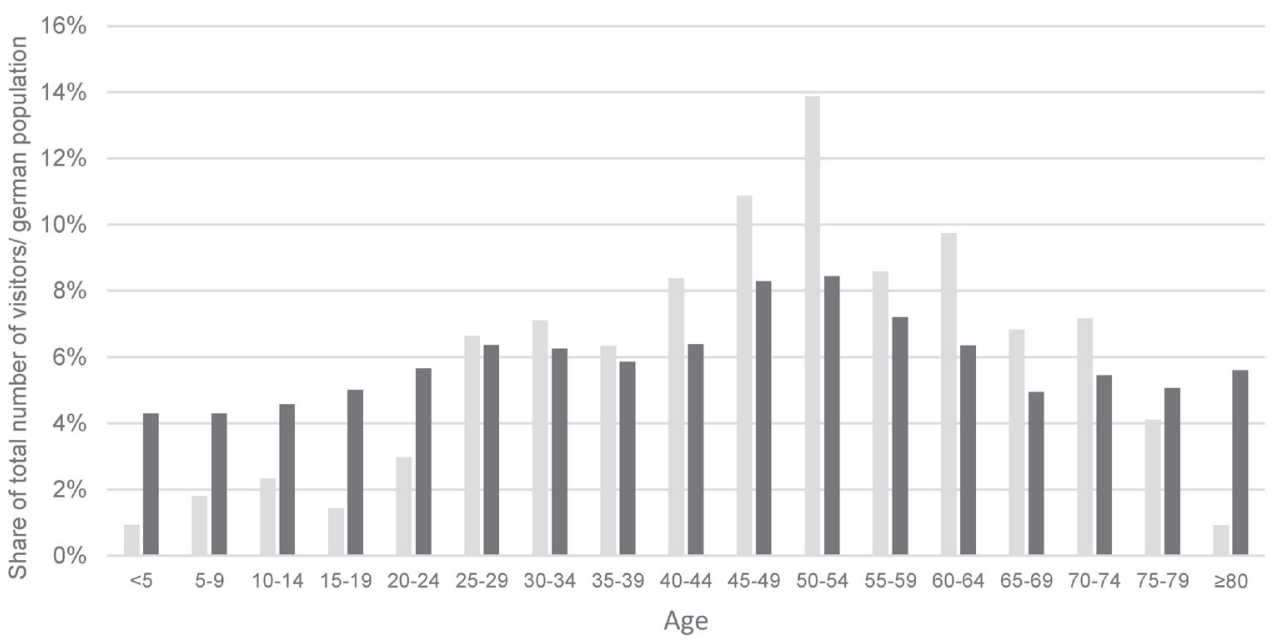

- Visitors of Berchtesgaden NP (short interviews, $n=9460)$ n German population (source: Statistisches Bundesamt 2016)

Figure 1 - Age distribution of visitors to Berchtesgaden NP compared to German population.

stops, mode detection and map-matching. Data filtering was done manually, based on criteria of Beeco et al. (2013), and stops were identified, with a minimum stop duration of five minutes (Thierry et al. 2013). Afterwards GPS points were mapped to the trail network, which at the same time smooths the data and converts it from point to line geometry using the mapmatching algorithm of Haunert and Budig (2012). Finally, the trajectories were split up into $100 \mathrm{~m} \mathrm{seg-}$ ments and intersected with the trail network. A buffer of $25 \mathrm{~m}$ was created around the points of interest and intersected with the stops.

\section{Data analysis}

The trajectories and questionnaires were weighted with the number of visitors per season, age bracket and interview location to reflect the basic population in the study area. After post-processing, spatial behaviour is described by numerical parameters, which allows the identification of similar space-time behaviour by applying clustering techniques of static data (XiaoTing \& Bi-Hu 2012). In a first step, parameters were normalized with the number of days visitors were hiking in the area. The variables trip length, elevation gain and loss, slope of trails and trail difficulty were zstandardized and served as input variables in k-means clustering to determine activity types. Prior to k-means clustering three outliers were identified using singlelinkage procedure. The algorithm was run 5000 times and a one to seven cluster solution was tried. Based on the criteria of proportional reduction of error (Bacher 2008, 307) two, four and six cluster solutions were possible. As ward clustering also suggested a solution with four clusters, this was finally chosen.

\section{Demographic scenarios}

To determine potential impacts of demographic change on the spatial behaviour of visitors, three scenarios were constructed, assuming an age effect. In these three scenarios the share of groups with one or more visitors aged $60+$ is increased from currently $32 \%$ to $40 \%$ (scenario 1 ), $48 \%$ (scenario 2 ) and $56 \%$ (scenario 3), with the share of other age brackets declining accordingly. The scenarios should reflect possible situations in the year 2040, with scenario 2 being the most likely scenario. It considers today's visits by age bracket and the age composition in groups in connection with a changing age distribution in the German population. Consequently, scenarios 1 and 3 can be seen as a low impact or high impact scenario of demographic change.

\section{Results}

Age distribution and visitor characteristics

Visitors to Berchtesgaden NP below the age of 25 and over 79 years are underrepresented compared to the German population, whereas visitors aged 40 to 74 are overrepresented (see Figure 1).

Age groups differ significantly in their gender composition, with a higher proportion of all-male groups with the oldest person between 15 and 49 years and over 70 (see Table 1). Older adults and people aged $60+$ tend to stay longer in the region, whereas young adults aged 15 to 39 visit the NP more often during a daytrip than other age brackets. Age brackets also have different motives for visiting the study area. Primary motive for groups of young adults aged 15 to 39 to do something exciting, whereas groups with the oldest member aged $70+$ want to discover something new and experience nature.

\section{Activity types}

$\mathrm{K}$-means clustering resulted in a four cluster solution (see Table 2 and Figure 2), which describes four activity types and their spatio-temporal behaviour.

Mountaineers (11.2\% of all groups) spend more than six hours in the NP and hike a distance of $9.4 \mathrm{~km}$. They gain $751 \mathrm{~m}$ in elevation, as much as the Ambitious bikers do. Their resting time is highest, as well as the 
Table 2 - Route characteristics of four activity types. ${ }^{*} p<0.05 ;{ }^{* *} p<0.01 ;{ }^{* * *} p<0.001$

\begin{tabular}{|c|c|c|c|c|c|c|}
\hline & Mountaineer & Ambitious Hiker & \begin{tabular}{|l|} 
Pleasure Hiker \\
\end{tabular} & Walker & Total & Test \\
\hline Length of trip (m) & 9400 & 14019 & 5746 & 3369 & 7062 & $\mathrm{~F}=347.4^{* * *}$ \\
\hline Elevation gain $(\mathrm{m})$ & 751 & 732 & 208 & 64 & 329 & $\mathrm{~F}=261.7^{* * *}$ \\
\hline Relative difference in elevation $(\mathrm{m})$ & -65 & -268 & -63 & 0 & -84 & $F=18.3^{\cdots}$ \\
\hline Duration of hiking incl. stops (min) & 374 & 362 & 211 & 189 & 254 & $F=76.6^{* * *}$ \\
\hline Duration of stops (min) & 108 & 76 & 59 & 57 & 68 & $F=17.1^{\cdots}$ \\
\hline Number of stops & 7 & 4 & 3 & 3 & 4 & $F=47.7^{\cdots \cdots}$ \\
\hline Minutes between stop (min) & 45 & 80 & 58 & 37 & 54 & $F=31.3^{\cdots}$ \\
\hline Start-time (hh:mm) & $09: 30$ & $10: 12$ & $11: 42$ & $11: 49$ & $11: 11$ & \\
\hline Walking speed $(\mathrm{km} / \mathrm{h})$ & 2.3 & 3.2 & 2.7 & 2.3 & 2.6 & $F=27.9^{\cdots *}$ \\
\hline Share of retraced trails & $39.4 \%$ & $32.4 \%$ & $38.0 \%$ & $67.0 \%$ & $48 \%$ & $\mathrm{~F}=41.3^{\cdots *}$ \\
\hline Startpoint = Endpoint & $85.2 \%$ & $80.6 \%$ & $91.1 \%$ & $100.0 \%$ & $91 \%$ & $\mathrm{Chi}^{2}=37.9^{\cdots *}$ \\
\hline Transportation used & $42.6 \%$ & $57.7 \%$ & $44.2 \%$ & $54.2 \%$ & $51 \%$ & $\mathrm{Chi}^{2}=6.8$ \\
\hline Share of trails scale 1 & $12.0 \%$ & $13.1 \%$ & $27.2 \%$ & $74.3 \%$ & $40 \%$ & $F=389.3^{* \cdots}$ \\
\hline Share of trails scale 2 & $35.9 \%$ & $60.7 \%$ & $62.9 \%$ & $21.9 \%$ & $44 \%$ & $F=160^{* * *}$ \\
\hline Share of trails scale 3 & $39.0 \%$ & $24.4 \%$ & $9.5 \%$ & $3.7 \%$ & $14 \%$ & $\mathrm{~F}=120^{* * *}$ \\
\hline Share of trails scale 4 & $13.1 \%$ & $0.9 \%$ & $0.0 \%$ & $0.0 \%$ & $2 \%$ & $F=405.5^{n+*}$ \\
\hline Peak visited & $24.1 \%$ & $31.1 \%$ & $4.8 \%$ & $0.0 \%$ & $11 \%$ & $\mathrm{Chi}^{2}=80.5^{* *+}$ \\
\hline Slope under $10 \%$ & $31.9 \%$ & $40.4 \%$ & $62.1 \%$ & $92.7 \%$ & $65 \%$ & $\mathrm{~F}=419^{\cdots *}$ \\
\hline Slope between $10 \%$ and $20 \%$ & $27.8 \%$ & $40.5 \%$ & $27.3 \%$ & $5.1 \%$ & $22 \%$ & $F=314.8^{* * *}$ \\
\hline Slope between $20 \%$ and $35 \%$ & $25.8 \%$ & $15.3 \%$ & $7.3 \%$ & $0.3 \%$ & $9 \%$ & $F=192.5^{\ldots \prime}$ \\
\hline Slope over $35 \%$ & $11.0 \%$ & $1.7 \%$ & $0.2 \%$ & $0.1 \%$ & $2 \%$ & $\mathrm{~F}=408.7^{* * *}$ \\
\hline Used hiking path & $61.8 \%$ & $39.9 \%$ & $34.6 \%$ & $22.3 \%$ & $34 \%$ & $F=50.1^{* * *}$ \\
\hline Used minor service road & $25.9 \%$ & $38.6 \%$ & $40.4 \%$ & $27.7 \%$ & $34 \%$ & $F=13^{\cdots *}$ \\
\hline Used major service road & $12.3 \%$ & $21.4 \%$ & $25.0 \%$ & $50.0 \%$ & $32 \%$ & $F=83^{\prime \prime}$ \\
\hline Used sign-posted trails & $97.6 \%$ & $96.4 \%$ & $96.4 \%$ & $97.6 \%$ & $97 \%$ & $F=1.2$ \\
\hline Took trails with no view & $55.4 \%$ & $48.2 \%$ & $43.1 \%$ & $18.9 \%$ & $37 \%$ & $\mathrm{~F}=97.8^{* * *}$ \\
\hline Took trails with one valley view & $20.8 \%$ & $13.1 \%$ & $32.6 \%$ & $71.1 \%$ & $41 \%$ & $F=177.4^{\prime \prime *}$ \\
\hline Took trails with two valley view & $16.8 \%$ & $30.7 \%$ & $18.8 \%$ & $9.8 \%$ & $18 \%$ & $F=33.1^{\cdots \cdots}$ \\
\hline Took trails with panoramic view & $7.0 \%$ & $8.0 \%$ & $5.5 \%$ & $0.1 \%$ & $4 \%$ & $F=20.3^{\cdots}$ \\
\hline Waterside trail & $6.9 \%$ & $4.1 \%$ & $19.5 \%$ & $33.9 \%$ & $20 \%$ & $F=71.6^{* *}$ \\
\hline Trail through grassland & $17.8 \%$ & $35.8 \%$ & $23.5 \%$ & $9.4 \%$ & $20 \%$ & $F=43.1^{\cdots *}$ \\
\hline Trail through rock & $11.3 \%$ & $3.2 \%$ & $0.7 \%$ & $0.3 \%$ & $2 \%$ & $\mathrm{~F}=89.4^{* \cdots}$ \\
\hline Trail through forest & $57.3 \%$ & $51.9 \%$ & $43.7 \%$ & $18.8 \%$ & $38 \%$ & $F=116^{* *}$ \\
\hline Trail through man made & $6.6 \%$ & $4.9 \%$ & $12.7 \%$ & $37.6 \%$ & $19 \%$ & $F=106.5^{\prime * *}$ \\
\hline Trails of low frequentation & $39.2 \%$ & $54.7 \%$ & $31.9 \%$ & $23.7 \%$ & $35 \%$ & $F=18.6^{\cdots *}$ \\
\hline Trails of medium frequentation & $53.5 \%$ & $41.8 \%$ & $57.1 \%$ & $44.0 \%$ & $49 \%$ & $F=6.4^{\cdots *}$ \\
\hline Trails of high frequentation & $7.2 \%$ & $3.5 \%$ & $11.0 \%$ & $32.3 \%$ & $17 \%$ & $\mathrm{~F}=32.3^{\cdots *}$ \\
\hline
\end{tabular}

number of stops and they start earliest of all activity types. A major difference from the other activity types is that they hike on trails with the danger of falls and very steep mountain paths. This activity type also follows sign-posted trails through forest grassland and rock. Compared to other activity types, they avoid service roads. Apart from a concentration north of Lake Königssee, where a via ferrata is situated, Mountaineers present a dispersed pattern.

Ambitious bikers (21.5\% of all groups) cover the longest distance of all activity types with $14.0 \mathrm{~km}$ and gain $732 \mathrm{~m}$ in elevation. They are the fastest activity type and are hiking the longest before making a stop. They hike almost exclusively on trails that lead through forest or grassland with a large field of view. If possible, they avoid walking there and back on the same trail and end most often in a different place from where they started. Ambitious hikers also present a dispersed pattern and can be found throughout the NP, especially east of Lake Königssee.
Pleasure hikers (30.5\% of all groups) are hiking only half a day in the area and are walking less than half the distance $(5.7 \mathrm{~km})$ of the Ambitious hikers and less than a third of the elevation (208 m elevation gain). They avoid steep slopes and rough trails and most often take medium frequented trails. This activity type predominantly hikes in the three valleys of the study area and in the area of Mount Jenner. In a multi-day trip, Pleasure bikers can also reach the remote areas in the south of the NP.

Walkers (36.8\% of all groups) cover only $3.4 \mathrm{~km}$ in the area in slightly over three hours and gain only $64 \mathrm{~m}$ in elevation. They spend almost one third of their stay at stops and take almost only trails with an even surface and slopes under $10 \%$. Their preferred trails run along water bodies or through built infrastructure and present mainly medium or high frequency. Walkers are highly concentrated in the three valleys and at Mount Jenner, where the cable car is located. 

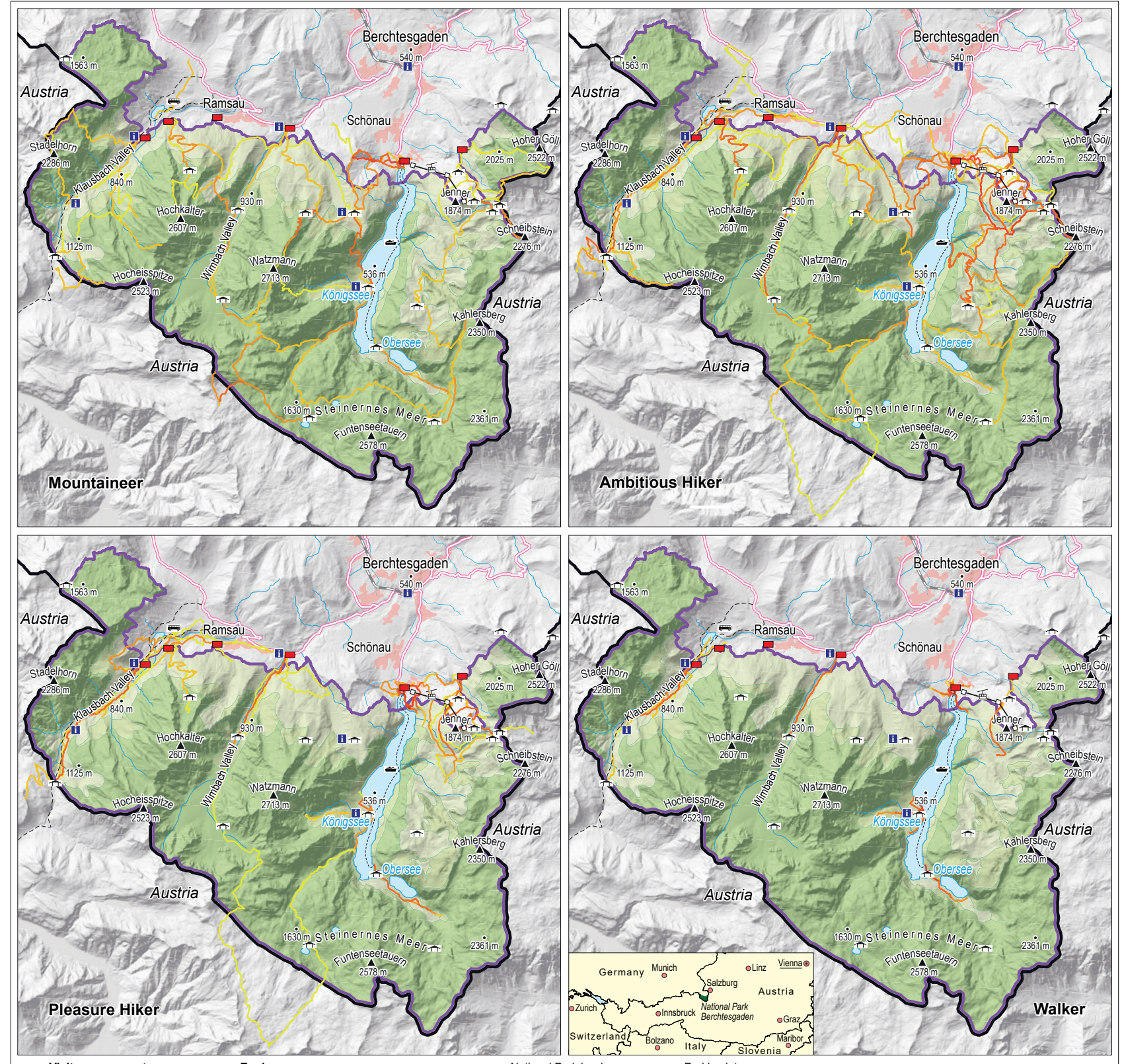

Visitor movements per trail segment per ye

Zoning
$\square$ Core zone

- up to 2.500

Temporary management zone

Permanent management zone
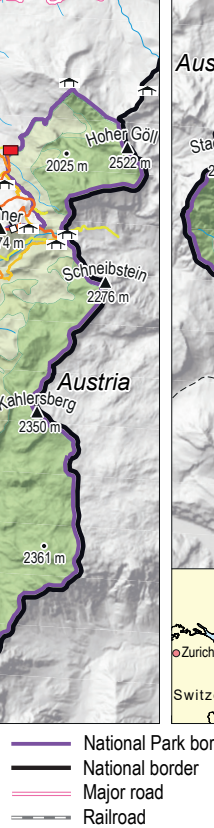

- Parking lot

i. National Park information

o. Waters

— $>25.000$ to 100.000

— $>100.000$ to 250.000

4. Settlement

Figure 2 - Spatial behaviour of the four activity types.

Activity types per age bracket and gender

Table 3 shows the distribution of the four activity types by age bracket and gender. Age refers to minimum age if groups with children under 15 were encountered, otherwise it refers to the maximum age in the group. When defining age brackets in this way, the relation between age bracket and activity is stronger $\left(\mathrm{Chi}^{2}=102.4^{* * *}\right.$; Cramer's V 0.267), compared to age groupings based on the age of respondent $\left(\mathrm{Chi}^{2}=48.9^{* * *}\right.$; Cramer's V 0.184) or average group age $\left(\mathrm{Chi}^{2}=47.3^{* * *}\right.$; Cramer's V 0.181). Almost half (44.8\%) of the groups with children can be classified as Walkers. Ambitious hikers (14.9\%) and Mountaineers (1.5\%) are a minority. When the oldest member of the group is 50 to 59 years of age, the share of Mountaineers falls sharply $(5.0 \%)$ and the share of Pleasure bikers rises $(36.6 \%)$. More than half of the groups with senior visitors aged $60+$ are Walkers, whereas Mountaineers and Ambitious bikers have a combined share of less than $20 \%$.

Almost one third (31.3\%) of all-male groups can be classified as Mountaineers, which clearly separates them from all-female or mixed gender groups $\left(\mathrm{Chi}^{2}=72.2^{* * *}\right.$; Cramer's V 0.274). 
Table 3 - Demographic profile of the four activity types. ${ }^{a}$ Refers to youngest group member if it is younger than 15, otherwise oldest group member; ${ }^{*} p<0.05 ;{ }^{* *} p<0.01 ;{ }^{* * *} p<0.001$

\begin{tabular}{|c|c|c|c|c|c|c|}
\hline & & $\begin{array}{l}\begin{array}{l}\text { Mountaineer } \\
(\mathrm{n}=54)\end{array} \\
\end{array}$ & $\begin{array}{l}\text { Ambitious hiker } \\
(n=103)\end{array}$ & \begin{tabular}{|l|} 
Pleasure hiker \\
$(n=147)$
\end{tabular} & \begin{tabular}{|l|} 
Walker \\
$(n=177)$
\end{tabular} & Test \\
\hline \multirow{6}{*}{$\mathrm{Age}^{a}$} & Under 15 & $1.5 \%$ & $14.9 \%$ & $38.8 \%$ & $44.8 \%$ & \multirow{6}{*}{$\mathrm{Chi}^{2}=102.4^{\cdots \cdots} ;$ Cramer's V 0.267} \\
\hline & 15 to 39 & $23.8 \%$ & $34.5 \%$ & $21.4 \%$ & $20.2 \%$ & \\
\hline & 40 to 49 & $24.7 \%$ & $27.4 \%$ & $23.3 \%$ & $24.7 \%$ & \\
\hline & 50 to 59 & $5.0 \%$ & $32.7 \%$ & $36.6 \%$ & $25.7 \%$ & \\
\hline & 60 to 69 & $4.4 \%$ & $5.6 \%$ & $34.4 \%$ & $55.6 \%$ & \\
\hline & 70 and older & $9.2 \%$ & $9.2 \%$ & $26.2 \%$ & $55.4 \%$ & \\
\hline \multirow{3}{*}{$\begin{array}{l}\text { Gender composition } \\
\text { of group }\end{array}$} & All-male & $31.3 \%$ & $32.3 \%$ & $13.1 \%$ & $23.2 \%$ & \multirow{3}{*}{$\mathrm{Chi}^{2}=72.2^{* *} ;$ Cramer's V 0.274} \\
\hline & All-female & $3.7 \%$ & $25.9 \%$ & $40.7 \%$ & $29.6 \%$ & \\
\hline & Mixed & $6.2 \%$ & $18.3 \%$ & $34.3 \%$ & $41.3 \%$ & \\
\hline
\end{tabular}

\section{Scenario older visitors}

Assuming an age effect, Table 4 reveals that with ageing visitors the share of Mountaineers, and especially the share of Ambitious bikers, goes down, while the share of Pleasure bikers stays constant and the share of Walkers goes up.

Figure 3 displays the change in the use of trails in scenario 2 compared to the current situation. In two valleys, the Klausbach Valley and the Königssee Valley, trail use will increase up to $12 \%$, whereas in the third valley, along Wimbach River, trail use will decrease slightly. In remote areas in the south of the NP and in mountain areas like on Watzmann, demographic change will cause a decline in visitor movements of up to $16 \%$ for scenario 2 . The map further reveals that visitor movements will go down on all trails leading through the core zone of the NP, while trails in the management zone of the $\mathrm{NP}$ will see an increased frequency of visitors. In the other two scenarios the spatial patterns of increase and decrease in frequentation of trails is similar but the intensity of change varies.

\section{Discussion}

In the study area more than one third of the visitors $(36.8 \%)$ were classified as Walkers, who cover on average less than $4 \mathrm{~km}$ and gain less than $100 \mathrm{~m}$ in elevation. Thus the share of very short hikes is more than four times higher than found by Rupf (2015, 143), who investigated a mountain hiking region in Switzerland. Most people of this activity type walk in the area around Lake Königssee. This area has a unique position within the NP as it is an internationally known attraction which also offers cultural sights. The service arrangement and the primary motive of visitors to Lake Königssee often differs from that of other NP visitors and does not focus on sports and physical activity (Butzmann \& Job 2016). Moreover, a significant share of visitors to Lake Königssee are from abroad, participating in fully standardized tours, which limits their time budget in the study area. Only a minority of the visitors $(11.2 \%)$ can be classified as Mountaineers, who prefer trails with a danger of falling, a trail type that is closely associated with Alpine mountains. This finding is consistent with re-
Table 4 - Four activity types under varying demographic scenarios assuming an age effect.

\begin{tabular}{|l|r|r|r|r|}
\cline { 2 - 5 } \multicolumn{1}{c|}{} & Today & Scenario 1 & Scenario 2 & Scenario 3 \\
\hline Mountaineer & $11.2 \%$ & $10.7 \%$ & $10.1 \%$ & $9.5 \%$ \\
\hline Ambitious hiker & $21.5 \%$ & $19.7 \%$ & $18.0 \%$ & $16.3 \%$ \\
\hline Pleasure hiker & $30.5 \%$ & $30.5 \%$ & $30.5 \%$ & $30.6 \%$ \\
\hline Walker & $36.8 \%$ & $39.1 \%$ & $41.3 \%$ & $43.5 \%$ \\
\hline
\end{tabular}

sults from other areas in the Alps (Fischer et al. 2015; Brämer 2005).

Groups with children hardly undertake demanding hikes on trails with the danger of falling. From the age of 50 the share of Mountaineers falls sharply and visitors aged $60+$ clearly prefer short walks or moderate hikes. This corresponds to the findings of Muhar et al. (2007). They revealed that hikers aged $60+$ and children under 14 make up well below $10 \%$ of all outdoor recreationists who go on demanding hikes or can be classified as mountaineers.

With increasing age, skills required for mountain hiking are rated lower, while health restrictions increase. This is in line with findings from sports medicine (Burtscher 2004). According to constraint research, the perception of a constraint to outdoor recreation, such as the perceived lack of skill, does not necessarily result in non-participation in an activity. Instead outdoor recreationists alter their preferences for a certain activity and continue to participate (Walker \& Virden 2005; Jackson et al. 1993), especially if motivation is high (White 2008). So it seems that the preference of older visitors for shorter and well maintained trails with an even surface can in part be explained as a reaction to a perceived lack of skill and to health restrictions (Trachsel \& Backhaus 2011). However, if constraints are severe, negotiation through constraints may become impossible and people stop participating in an activity. This may explain why people aged 80 engage less in activities on foot (BMWI 2010).

Even though tourism researcher assume that future generations of seniors will be fitter and healthier than today's generation of seniors (Glover \& Prideaux 2009), an age effect was assumed for the construction of the scenarios. This was reasoned by the fact that 


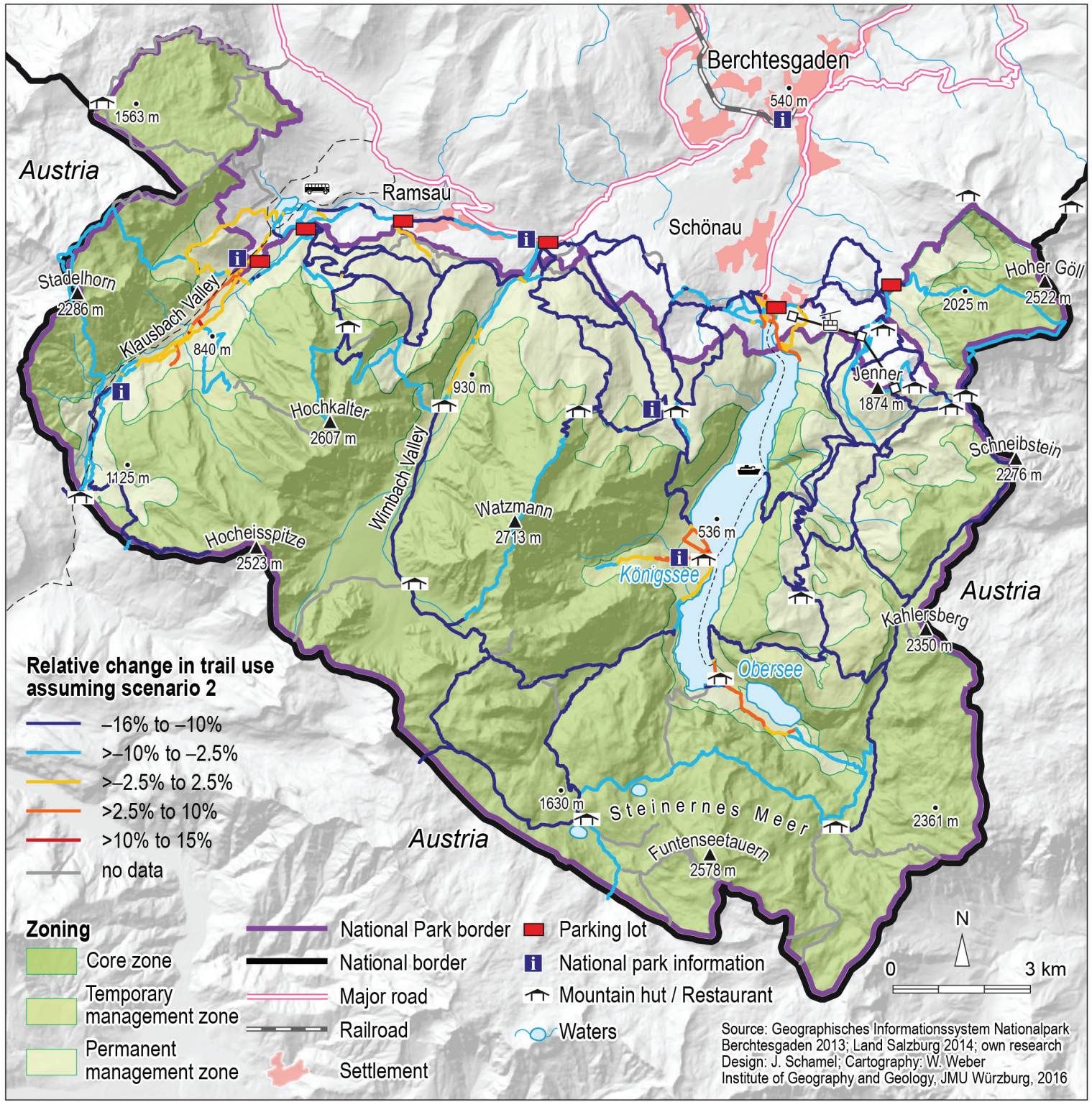

Figure 3 - Change in trail use with share of groups aged $60+$ increasing from $32 \%$ to $48 \%$.

studies on physical activity and ageing conducted in different contexts revealed the consistent finding that vigorous activities, like walking uphill (Ainsworth et al. 2000), decrease strongly with age (Colley et al. 2011; Troiano et al. 2008).

In the depicted scenarios the concentration of visitors rises slightly, caused by a growing importance of Walkers and the fact that visitors of this activity type often walk there and back on the same trail. However, spatial displacement in reaction to an increased perception of crowding, as seen in other recreational areas (Schamel \& Job 2013), could counteract the concentration of visitors caused by demographic change.

As the forecast only considered demographic change as influencing variable on spatial behaviour, other factors, like constantly changing preferences for outdoor recreation and the ongoing diversification of activities (Strasdas et al. 1994), were not included in the forecast. Nevertheless, the finding how the share of the four activity types may be influenced by demographic change provides valuable information for visitor management and marketing of the NP.

\section{Conclusion}

The study revealed that more than two thirds of the visitors stay in the area for only half a day and can be classified as Walkers or Pleasure bikers. Several turning points in the life cycle exist, when spatial behaviour changes: age brackets of young and middle-aged adults are quite homogenous in their activities up to the age of 50. Thereafter the share of Mountaineers decreases significantly. Visitors aged $60+$ clearly prefer short walks, with a sharp decrease in demanding hikes in this age group.

The findings may help managers of the NP to anticipate demographic change in their future visitor management concepts. Crowding may become a more 
prominent issue in two valleys, especially as visitors in these areas tend to walk there and back on the same trail.

This study has several limitations. Only major access points to the NP were covered and a larger sample size is needed to evaluate the impact of demographic change on the frequentation of one specific trail in more detail, especially in less frequented areas. Another limitation is that the missing values of GPS data are not randomly distributed across the study area, as signal quality is influenced by environmental features. Lastly, spatial displacement in reaction to crowding was not included. Future research could use multi-agent simulations to cover this effect.

\section{Acknowledgements}

This project was funded by the German Research Foundation (DFG, GZ JO 338/9-1).

\section{References}

Ainsworth, B.E., W.L. Haskell, M.C. Whitt, M.L. Irwin, A.M. Swartz \& S.J. Strath 2000. Compendium of physical activities: an update of activity codes and MET intensities. Medicine and science in sports and exercise 32(9 Supplement): 498-504.

Arrowsmith, C., D. Zanon \& P. Chhetri 2005. Monitoring Visitor Patterns of Use in Natural Tourist Destinations. In: Ryan C., S.J. Page \& M. Aicken (eds.), Taking Tourism to the Limits. Issues, Concepts and Managerial Perpectives: 33-52. Kidlington.

Bacher, Johann 2008. Clusteranalyse. Anwendungsorientierte Einfübrung. München. [In German]

Beeco, J., A. \& J.C. Hallo 2014. GPS Tracking of Visitor Use: Factors Influencing Visitor Spatial Behavior on a Complex Trail System. Journal of Park and Recreation Administration 32(2): 43-61.

Beeco, J.A., J.C. Hallo, W. English \& G.W. Giumetti 2013. The importance of spatial nested data in understanding the relationship between visitor use and landscape impacts. Applied Geography 45: 147-157.

Beeco, J.A., W.J. Huang, J.C. Hallo, W.C. Norman, N.G. McGehee, J. McGee \& C. Goetcheus 2012. GPS Tracking of Travel Routes of Wanderers and Planners. Tourism Geographies: 1-23.

Bowker, J. M., A.E. Askew, H. K. Cordell, C.J. Betz, S.J. Zarnoch \& L. Seymour 2012. Outdoor recreation participation in the United States - projections to 2060: a technical document supporting the Forest Service 2010 RPA Assessment (General Technical Report, SRS-160). Asheville.

Bowker, J.K, D. Murphy, H.K. Cordell, D.B.K. English, C. Bergström, C.M. Starbuck, C.J. Betz \& G.T. Green 2006. Wilderness and Primitive Area Recreation Participation and Consumption: An Examination of Demographic and Spatial Factors. Journal of Agricultural and Applied Economics 38(2): 317-326.

Brämer, R. 2005. Profilstudie Wandern '04 - Bergwandern im Allgäu. Available at http://www.wan- derforschung.de/files/bergallgaeu041252860181.pdf (accessed: 13/01/2016). [In German]

Breuer, C., K. Hallmann, P. Wicker \& S. Feiler 2010. Socio-economic patterns of sport demand and ageing. European Review of Aging and Physical Activity 7(2): 61-70

BMWI - Bundesministerium für Wirtschaft und Technologie (ed.) 2010. Grundlagenuntersuchung Freizeit und Urlaubsmarkt Wandern (Forschungsbericht 591). Available at https://www.bmwi.de/BMWi/ Redaktion / PDF/Publikationen / Studien / grundlagenuntersuchung-freizeit-und-urlaubsmarktwandern,property $=$ pdf, bereich $=$ bmwi, pprache $=$ de, $r$ w b=true.pdf (accessed: 24/02/2015) [In German]

Burtscher, M. 2004. Endurance performance of the elderly mountaineer: Requirements, limitations, testing, and training. Wien Klin Wochenschr 116(21-22): 703-714.

Butzmann, E. \& H. Job 2016. Developing a Typology for Sustainable National Park Tourism Products. Journal of Sustainable Tourism.

Colley, R.C., D. Garriguet, I. Janssen, C.L. Craig, J. Clarke \& M.S. Tremblay 2011. Physical activity of Canadian adults: accelerometer results from the 2007 to 2009 Canadian Health Measures Survey. In: Health reports 22(1): 7-14.

Destatis (eds.) 2015. Bevölkerung Deutschlands bis 2060. Ergebnisse der 13. koordinierten Bevölkerungsvorausberechnung. Available at https://www. destatis.de/DE/ZahlenFakten/GesellschaftStaat/ Bevoelkerung/Bevoelkerungsvorausberechnung/ Bevoelkerungsvorausberechnung.html (accessed 25/11/2015). [In German]

Eagles, P. 2007. Global Trends Affecting Tourism in Protected Areas. In: Bushell, R. \& P. Eagles (eds.), Tourism and Protected Areas. Benefits Beyond Boundaries: 27-43. Wallingford.

Farias Torbidoni, E., H.R. Grau \& A. Camps 2005. Trail Preferences and Visitor Characteristics in Aigüestortes i Estany de Sant Maurici National Park, Spain. Mountain Research and Development 25(1): 51-59.

Fischer, A., M. Lamprecht \& H.P Stamm 2015. Wandern in der Schweiz 2014. Available at: http://www. wandern.ch/de/downloads (accessed 25/9/2015). [In German]

Glover, P. \& B. Prideaux 2009. Implications of population ageing for the development of tourism products and destinations. Journal of Vacation Marketing 15(1): 25-37.

Hallo, J.C., J.A Beeco, C. Goetcheus, J. McGee, N.G. McGehee \& W.C. Norman 2012. GPS as a Method for Assessing Spatial and Temporal Use Distributions of Nature-Based Tourists. Journal of Travel Research 51(5): 591-606.

Haunert, J.H. \& B. Budig 2012. An algorithm for map matching given incomplete road data. In: ACM (eds.): Proceedings of the 20 $0^{\text {th }}$ International Conference on Advances in Geographic Information Systems: 510-513. Redondo Beach. 
Jackson, E.L., D.W. Crawford, \& G. Godbey 1993. Negotiation of leisure constraints. Leisure Sciences 15(1): 1-11.

Job, H. 1991. Tourismus versus Naturschutz: sanfte Besucherlenkung in (Nah-)Erholungsgebieten. Naturschutr. und Landschaftsplanung 23(1): 28-34. [In German]

Job, H., B. Harrer, D. Metzler \& D. HajizadehAlamdary 2005. Ökonomische Effekte von Großschutzgebieten. Leitfaden zur Erfassung der regionalwirtschaftlichen Wirkungen des Tourismus in Großschutzgebieten (BfN-Skripten, 151). Bonn - Bad Godesberg. [In German]

Job, H. \& D. Metzler 2005. Regionalökonomische Effekte von Großschutzgebieten. Natur und Landschaft 80(11): 465-471. [In German]

Kerr, J., S. Duncan \& J. Schipperijn 2011. Using global positioning systems in health research: a practical approach to data collection and processing. American journal of preventive medicine 41(5): 532-540.

McFarlane, B.L., P. Boxall \& D. Watson 1998. Past Experience and Behavioral Choice Among Wilderness Users. Journal of Leisure Research 30(2): 195-213.

Meijles, E.W., M. de Bakker, P.D. Groote \& R. Barske 2014. Analysing hiker movement patterns using GPS data: Implications for park management. Computers, Environment and Urban Systems 47: 44-57.

Metzler, D., M. Woltering \& N. Scheder 2016. Naturtourismus in Deutschlands Nationalparks. Natur und Landschaft 91(1): 8-14. [In German]

Muhar, A., T. Schauppenlehner, C. Brandenburg \& A. Arnberger 2007. Alpine summer tourism: the mountaineers' perspective and consequences for tourism strategies in Austria. Forest, Snow and Landscape Research 81(1/2): 7-17.

Pennington-Gray, L., D.L. Kerstetter \& R. Warnick 2002. Forecasting Travel Patterns Using Palmore's Cohort Analysis. Journal of Travel \& Tourism Marketing 13(1-2): 125-143.

Rupf, R. 2015. Planungsinstrumente für Wandern und Mountainbiking in Berggebieten unter besonderer Berücksichtigung der Biosfera Val Müstair. Nationalpark-Forschung in der Schweiz 104. Bern. [In German]

Schamel, J. \& H. Job 2013. Crowding in Germany's national parks: the case of the low mountain range Saxon Switzerland National Park. eco.mont 5(1): 27-34.

Statistisches Bundesamt (ed.) 2016. Bevölkerung: Deutschland, Stichtag, Altersjahre. Available at: https://www-genesis.destatis.de/genesis/online (accessed 24/2/2016) [In German]

Strasdas, W., T. Jarosch \& H. Scharpf 1994. Auswirkungen neuer Freizeittrends auf die Umwelt. Aachen. [In German]
Taczanowska, K. 2009. Modelling the Spatial Distribution of Visitors in Recreational Areas. Dissertation. Universität für Bodenkultur, Wien.

Thierry, B., B. Chaix \& Y. Kestens 2013. Detecting activity locations from raw GPS data: a novel kernelbased algorithm. International journal of health geographics 12: 14 .

Trachsel, A. \& N. Backhaus 2011. Perception and needs of older visitors in the Swiss National Park: a qualitative study of hiking tourists over 55. eco.mont 3(1): 47-50.

Troiano, R.P., D. Berrigan, K.W. Dodd, L.C. Mâsse, T. Tilert \& M. McDowell 2008. Physical activity in the United States measured by accelerometer. Medicine and science in sports and exercise 40(1): 181-188.

van Marwijk, R. 2009. These routes are made for walking. Understanding the transactions between nature, recreational behaviour and environmental meanings in Dwingelderveld $\mathrm{Na}$ tional Park, the Netherlands. Dissertation. Wageningen University, Wageningen.

Vogel, M. 2011. Berchtesgaden National Park. eco. mont 3(1): 37-40.

Walker, G. \& R. Virden 2005. Constraints on Outdoor Recreation. In: E. L. Jackson (ed.), Constraints to Leisure: 201-219. State College.

White, D.D. 2008. A Structural Model of Leisure Constraints Negotiation in Outdoor Recreation. Leisure Sciences 30(4): 342-359.

Wolf, I.D. \& T. Wohlfart 2014. Walking, hiking and running in parks: A multidisciplinary assessment of health and well-being benefits. Landscape and Urban Planning 130: 89-103.

Xiao-Ting, H. \& W. Bi-Hu 2012. Intra-attraction Tourist Spatial-Temporal Behaviour Patterns. Tourism Geographies 14(4): 625-645.

\section{Author}

Johannes Schamel

is a doctoral student at the Institute of Geography and Geology in Würzburg. His scientific interests focus on issues of outdoor recreation in protected areas and visitor management. He specialized in quantitative analysis of spatio-temporal data using geographic information systems. Institute of Geography and Geology, Chair for Geography and Regional Science, Würzburg University, Germany. E-mail: johannes. schamel@uni-wuerzburg.de 